\title{
HABITUS PEDULI LINGKUNGAN : ANALISIS KEGIATAN LINGKUNGN BERBASIS PARTISIPATIF
}

\author{
Prasetyo Adi Nugroho \\ Institut Agama Islam Negeri Tulungagung \\ Prasetyoadinugoho1993@gmail.com
}

\begin{abstract}
Abstrak
Fokus penelitiaan adalah pada upaya pihak sekolah dalam membentuk kesadaran peserta didik terkait kondisi lingkungan dan komitmen peduli lingkungan. Penelitian menggunakan desain kualitatif dan menggunakan teknik pengumpulan data berupa observasi, wawancara, dokumentasi, kajian kepustakaan serta menggunakan teknik analisis data Miles dan Huberman yaitu, reduksi data, penyajian data, verifikasi. Hasil penelitian menunjukan komitmen peduli lingkungan belum terindikai didasari oleh pengetahuan dan kesadaran yang mendalam terkait kondisi lingkungan. Peserta didik terbatas pada aktivifitas bertindak tertib di lingkungan sekolah sebagaimana wacana disiplin lingkungan. Perilaku peserta didik dibentuk oleh habitus peduli lingkungan. Habitus menyediakan prinsip-prinsip yang akan memberikan aktor sebuah pilihan dan memilih strategi yang akan digunakan dalam kehidupan sosial. Habitus peduli lingkungan yang terepresentasi pada berbagai peraturan atau disiplin lingkungan dan kewajiban merawat tanaman menjadi satu-satunya pilihan dan strategi dalam melakukan berbagai aktivitas dan interaksi di lingkungan sekolah Adiwiyata.
\end{abstract}

Kata Kunci: Habitus, Peduli lingkungan, disiplin lingkungan

\section{Abstract}

The focus of research is on the efforts of the school in shaping students' awareness regarding environmental conditions and commitment to care for the environment. The study uses qualitative design and uses data collection techniques in the form of observation, interviews, documentation, literature review and using Miles and Huberman data analysis techniques, namely, data reduction, data presentation, verification. The results of the study show that the environmental care commitment has not been indexed based on deep knowledge and awareness regarding environmental conditions. Students are limited to activities acting orderly in the school environment as well as discourse on environmental discipline. The behavior of students is shaped by habitus caring for the environment. Habitus cares about the environment which is represented in various regulations or environmental discipline and the obligation to care for plants is the only choice and strategy in carrying out various activities and interactions in the Adiwiyata school environment.

Keywords: habits, Care for the environment, environmental discipline 


\section{PENDAHULUAN}

Pendidikan lingkungan hidup merupakan upaya responsif terhadap tekanan alam global. Ledakan jumlah penduduk berimplikasi pada peningkatan permintaan atas makanan, energi, dan perluasan lahan pemukiman sehingga terjadi reduksi hutan, krisis air bersih, polusi udara dan tanah, keanekaragaman hayati terancam, serta krisis cadangan energi (Susilastri dan Rustama, 2015). ${ }^{1}$ United Nation Conference on Environment and Development (UNICED) menyatakan pendidikan perlu menekankan kajian perkembangan populasi di dunia menyangkut lingkungan alam dan kompleksitas masalah sehingga berimplikasi pada pembentukan pengetahuan, sikap, motivasi, komitmen dan keterampilan untuk bekerja secara individu maupun kelompok dalam menghadapi masalah (Muhaimin, 2014). ${ }^{2}$ Indonesia memposisikan program Adiwiyata sebagai perwujudan pendidikan lingkungan hidup, yang mengemban misi mewujudkan warga sekolah yang bertanggung jawab dalam upaya perlindungan dan pengelolaan lingkungan hidup melalui tata kelola sekolah yang baik untuk mendukung pembangunan berkelanjutan (Mentri Lingkungan Hidup, 2013) ${ }^{3}$. Pernyataan UNICED dan Menteri Lingkungan Hidup merupakan komitmen global dalam menghadapi masalah lingkungan hidup.

Program Adiwiyata dilaksanakan dengan mendasarkan pada 4 standar implementasi, yaitu (1) Kebijakan sekolah berbasis lingkungan; (2) Kurikulum berbasis lingkungan; (3) Kegiatan lingkungan berbasis partisipatif; dan (4) Pengelolaan sarana dan prasarana ramah lingkungan hidup (Menteri Lingkungan Hidup, 2011) ${ }^{4}$. Standar implementasi pelaksanaan program Adiwiyata merupakan bentuk dari sosial order yang diharapkan tercapai dalam dunia sosial di sekolah dan kacamata lembaga lingkungan hidup.

Laporan penelitian menyatakan pendidikan lingkungan hidup kurang mampu membentuk kesadaran dan komitmen lingkungan kepada warga sekolah. Muhaimin (2014) menyatakan metode pelaksanaan pembalajaran pendidikan lingkungan hidup kurang

${ }^{1}$ Organitation for Economic Cooperation and Development (dalam Susilastri dan Rustaman, 2015, p. 263) menjelaskan bahwa faktor ledakan jumlah penduduk di-indikasikan sebagai penyebab utama peningkatan permintaan kebutuhan akan makanan, energi, dan perluasan lahan pemukiman. Permintaan diwujudkan dengan tereduksinya hutan, krisis sumber air bersih, kehilangan keanekaragaman hayati, krisis cadangan energi, polusi udara, polusi air dan polusi tanah. Organitation for Economic Cooperation and Development menyatakan ledakan jumlah penduduk dan berbagai aktivitas pemenuhan kebutuhan yang tidak memperhatikan etika lingkungan berimplikasi pada perubahan terhadap tekanan alam global.

${ }^{2}$ United Nation Conference on Environment and Development (UNICED, 1976 dalam Muhaimin, 2014 , p. 5) menyatakan, "...Is a proses aimed at developing a world population that of and concerned about the total environment and its associated problems, and which has the knowledge, attitudes, motivations, commitmens, and skills to work individually and collectively toward solutions of current problems and the prevention of new ones."

${ }^{3}$ Program Adiwiyata berusaha mengembangkan sekolah peduli dan berbudaya lingkungan atau sering disebut sekolah Adiwiyata (Mentri Lingkungan Hidup, 2013, p. 5).

${ }^{4}$ Program Adiwiyata merupakan salah satu program Kementrian Lingkungan Hidup dalam rangka mendorong terciptanya pengetahuan dan kesadaran warga sekolah dalam upaya pelestarian lingkungan hidup (Menteri Lingkungan Hidup, 2011, p. 2). 
aplikatif serta kurang mendukung penyelesaian permasalahan lingkungan hidup yang dihadapi daerah masing-masing. ${ }^{5}$ Untuk mengatasi masalah tersebut dilakukan beberapa penelitian pengembangan diantaranya, Muhaimin (2014) pengembangan model pembelajaran Ecopedagogy ${ }^{6}$, Pramana (2014) penerapan model PQ4R Kontekstual, ${ }^{7}$ Kumala (2014) dengan pemberian tugas pembuatan puzzle berbahan barang bekas untuk mengembangkan ekoliterasi. ${ }^{8}$ Strategi tersebut beraksentuasi pada pembelajaran berbasis masalah. Pada kajian lain, Terungwa dan Torkwase (2013) memaparkan tentang Current Issues in Flood Disaster: Challenges and Implications for Science and Technology to Enhance Environmental Education menunjukan kondisi yang sama. ${ }^{9}$

Berdasarkan analisis ujung depan di SMP kota Malang, kegiatan pembelajaran berbasis lingkungan dapat diamati pada tabel berikut ini,

\section{Tabel 1. Indikator Kurikulum berbasis Lingkungan}

\begin{tabular}{lll}
\hline \multicolumn{1}{c}{ Standar } & \multicolumn{1}{c}{ Pencapaian } & Hasil Pengamatan \\
Tenaga & Tenaga pendidik menerapkan & Tampak \\
pendidik & metode yang melibatkan & \\
memiliki & peserta didik secara aktif, & \\
kompetensi & antara lain: demonstrasi, & \\
dalam & diskusi kelompok, simulasi, & \\
mengembang & pengalaman lapangan, curah & \\
kan kegiatan & pendapat, debat, simposium, \\
pembelajaran & praktek lapangan, penugasan, \\
lingkungan & observasi, projek percontohan, \\
hidup & dll. & \\
& Tenaga pendidik & Tidak tampak \\
& mengembangkan isu lokal dan & \\
& isu global sebagai materi & \\
\hline
\end{tabular}

${ }^{5}$ Merujuk Kementrian Lingkungan Hidup, Muhaimin (2014) menjelaskan bahwa, "Materi dan metode pelaksanaan pembalajaran pendidikan lingkungan hidup kurang aplikatif. Pembelajaran LH kurang mendukung penyelesaian permasalahan lingkungan hidup yang dihadapi daerah masing-masing (KLH, 2004 dalam Muhaimin, 2014, p. 9).”

${ }^{6}$ Muhaimin. (2014) Pengembangan Model Pro-blem Based Learning dalam Ecopedagogy untuk Peningkatan Kompetensi ekologis mata pelajaran IPS. Disertasi Universitas Pendidikan Indonesia. respitory.upi.edu (Online) (diakses 26-02-2016).

${ }^{7}$ Pramana, KAB (2014) Pengaruh penerapan pembelajaran PQ4R kontekstual terhadap hasil belajar IPS dan sikap peduli Lingkungan siswa kelas V SD Gugus 1 Gianyar. E journal Program Pascasarjana Universitas Pendidikan Ganesha Program Studi Pendidikan Dasar (Volume 4 Tahun 2014).

${ }^{8}$ Kumala, N (2014) Pengembangan Ecoliteracy melalui Tugas Pembuatan Puzzle Berbahan Dasar Barang Bekas dalam Pembelajaran IPS. (Skripsi). Jurusan Ilmu Pengetahuan Sosial. Universitas Pendidikan Indonesia.

${ }^{9}$ Terungwa, Upa Callistus dan Torkwase, Iyortyer Clara (2013) Current Issues in Flood Disaster: Challenges and Implications for Science and Technology to Enhance Environmental Education. Academic Journal of Interdiciplinary Studies. Vol 2 No. 6 Agustus 2013. 


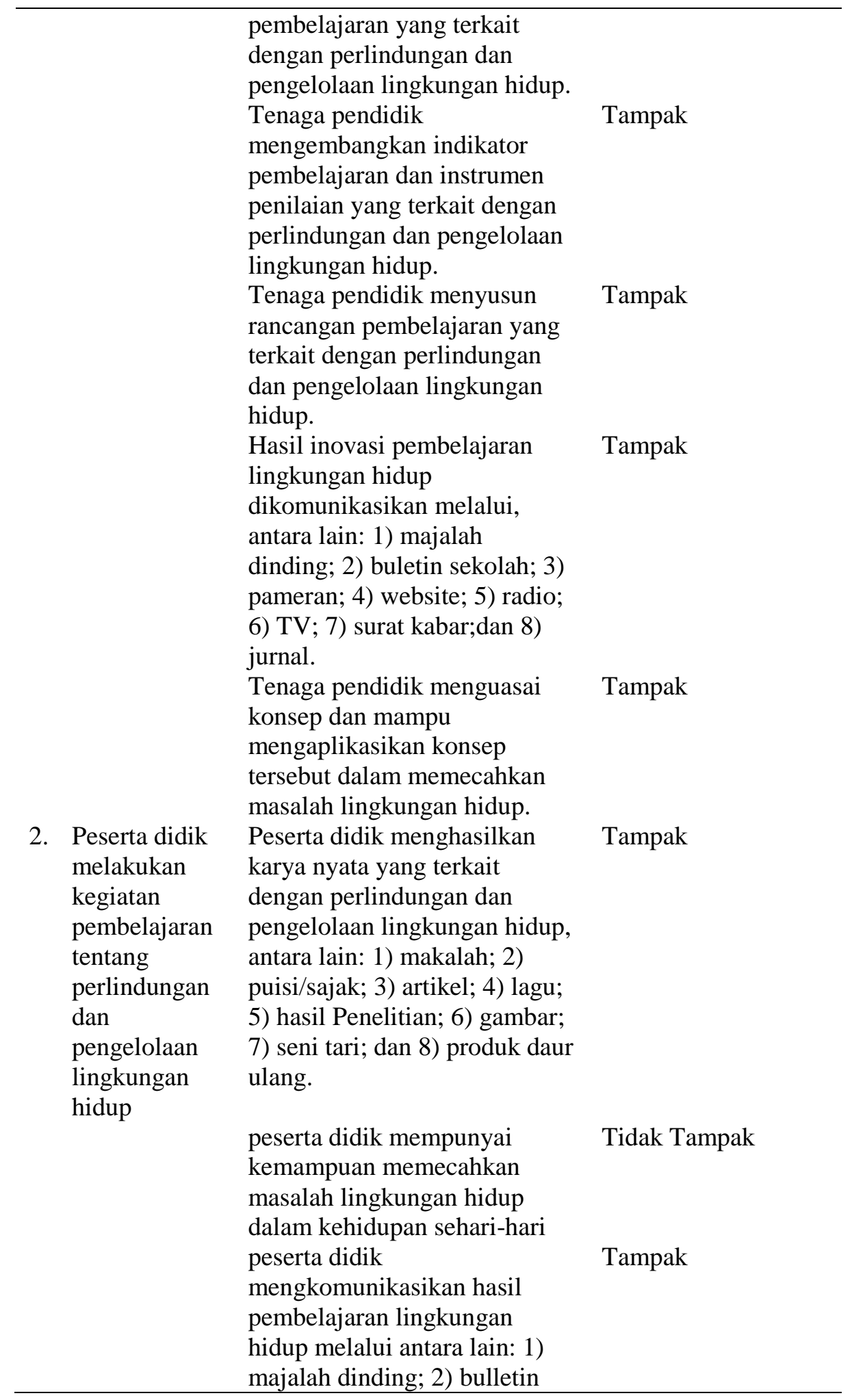


sekolah; 3) pameran;4)

website; 5) radio; 6) televisi; 7)

suratkabar; dan 8) jurnal.

Tabel merupakan hasil obeservasi pelaksanaan kurikulum berbasis lingkungan. Diperoleh data bahwa guru kurang memperhatikan isu masalah lingkungan di kota malang, disisi lain guru menekankan orientasi aktivitas terkait kebersihan kelas dan sekitar kelas, serta taman. Peserta didik belum memiliki kemampuan memecahkan masalah lingkungan hidup sehari-hari, oleh karena menganggap kegiatan yang dilakukan disekolah merupakan tugas yang diberikan oleh sekolah Adiwiyata. Pada aspek kegiatan lain di Sekolah Adiwiyata, ditemukan bahwa proses menciptakan pengetahuan dan kesadaran warga sekolah terhadap upaya pelestarian fungsi lingkungan menekankan kegiatan lingkungan berbasis partisipatif. Kegiatan tersebut diwujudkan dengan 1) pembentukan piket; 2) lomba kebersihan; 3) pemeliharaan taman; 4) pengomposan; 5) daur ulang. Kegiatan tersebut membentuk perilaku peserta didik untuk beraktivitas peduli dan berbudaya lingkungan di sekolah. Tetapi pada beberapa kajian peserta didik kurang memiliki pengetahuan dan kesadaran terhadap penurunan kualitas lingkungan sekitar kota Malang. Aktivitas peduli lingkungan dibentuk oleh peraturan yang disebut disiplin lingkungan. Penelitian ini berusaha menganalisis upaya pihak sekolah dalam membentuk kesadaran peserta didik terkait kondisi lingkungan dan komitmen peduli lingkungan.

\section{METODE}

Peneitian ini menggunakan desain penelitian kualitatif. Subjek penelitian adalah guru dan peserta didik SMP Adiwiyata kelas VIII di Kota Malang sehingga komponen penelitian adalah sistem sosial yang diproduksi dalam membentuk aktivitas peduli lingkungan. Proses pengumpulan data menggunakan observasi, wawancara, dokumentasi dan analisis kepustakaan. Teknik analisis data adalah koleksi data; reduksi; penyajian dan klasifikasi data; penarikan kesimpulan dan verifikasi. Pada dasarnya pada penelitian ini pengambilan kesimpulan telah dilakukan sejak awal berlangsungnya penelitian, namun terus dikembangkan dan diverifikasi selama berlangsung penelitian. Dalam verifikasi peneliti berusaha mencari data baru atau memperdalam penelitian. Pengujian kredibiltas data melalui upaya triangulasi sumber data, peningkatan ketekunan, member chek serta pengembangan sensitifitas peneliti melalui diskusi dengan para pakar dan membaca referensi yang relevan. ${ }^{10}$

${ }^{10}$ Cresswell, John W. (2012). Research Design Pendekatan Kualitatif, Kuantitatif, dan Mixed. Yogyakarta :PustakaPelajar. Creswell, John W. 2009. Research Design Qualitatif, Quantitatif, and Mixed Methods Approaches. Third Edition. United Kingdom: Sage Publiication Ltd. 


\section{PEMBAHASAN HASIL PENELITIAN}

Sekolah Adiwiyata menjadi fokus area dalam penelitian ini. Pengamatan dokumen Pancera Edisi 2 menunjukan bahwa sekolah menekankan habitus pada sivitas sekolah untuk menjaga lingkungan sekolah sebagai wujud cinta dan peduli lingkungan. Aktivitas tersebut dapat ditandai dengan salah satu kebijakan sekolah dengan menyuruh seluruh peserta didik baru tahun ajaran baru untuk membawa tanaman dalam pot ke sekolah. Berikut ungkapan Ana Lusiati bidang kurikulum terhadap salah satu staf di SMP Plus AlKautsar Malang, “...nanti semua siswa baru diberitahu untuk membawa tanaman dalam pot. Semuanya wajib membawa. Tanaman seperti di depan ruang guru ini pak..." (observasi tanggal 19 Juli). Pada tahap selanjutnya, peserta didik ditugaskan untuk bertanggung jawab atas tanaman yang telah dibawa, segaligus menjadi hak milik peserta didik. Tanaman tersebut harus dirawat dengan baik dan akan mendapat sanksi apabila tanaman tersebut mati.

Sikap mencintai dan peduli lingkungan diwujudkan dengan membiasakan peserta didik membuang sampah pada tempatnya dan pembinaan untuk memanfaatkan barang bekas agar dapat digunakan kembali. Berdasarkan majalah Pancera edisi 2 (p. 11), untuk menjaga prestasi sekolah sebagai sekolah Adiwiyata Mandiri diberlakukan disiplin lingkungan dengan memberi denda kepada sivitas yang melanggar aturan kebersihan. Berikut beberapa hasil karya peserta didik dalam mengolah sampah sebagai wujud reduce, reuse dan recycle. Tndakan yang dapat dilakukan berkaitan dengan program Reuse meliputi pilih produk dengan pengemas yang dapat didaur ulang, gunakan produk yang dapat diisi ulang ( refill), kurangi penggunaan bahan sekali pakai, plastik kresek digunakan untuk tempat sampah, kaleng/baskom besar digunakan untuk pot bunga atau tempat sampah, gelas atau botol plastik untuk pot bibit, dan macam-macam kerajinan, bekas kemasan plastik tebal isi ulang digunakan sebagai tas, styrofoam digunakan untuk alas pot atau lem, potongan kain/baju bekas untuk lap, keset, dan lain-lain, majalah atau buku untuk perpustakaan.

SMP Adiwiyata Malang berusaha mewujudkan tingkat efisiensi dan efektifitas pengelolaan sekolah dalam berbagai aspek kegiatan pendidikan, khususnya kegiatan pembelajaran. Berdasarkan temuan penelitian, komponen implementasi kurikulum berbasis lingkungan dengan indikator tenaga pendidik mengembangkan isu lokal dan isu global sebagai materi pembelajaran yang terkait dengan perlindungan dan pengelolaan lingkungan hidup berada pada posisi absen. Proses menciptakan pengetahuan dan kesadaran warga sekolah terhadap upaya pelestarian fungsi lingkungan menekankan kegiatan lingkungan berbasis partisipatif. Kegiatan tersebut diwujudkan dengan 1) pembentukan piket; 2) lomba kebersihan; 3) pemeliharaan taman; 4) pengomposan; 5) daur ulang. Kegiatan tersebut membentuk perilaku peserta didik untuk beraktivitas peduli dan berbudaya lingkungan. Aktivitas peduli lingkungan dibentuk oleh peraturan yang disebut disiplin lingkungan. 
Disiplin lingkungan merupakan salah satu bentuk nyata kegiatan lingkungan berbasis partisipatif oleh karena kegiatan berbasis peduli lingkungan di kontrol oleh sistem partisipasi. Gambar 1 ditujukan kepada pelanggar peraturan kebersihan, dimana ketika siswa masuk kedalam kelas membawa makanan dan minuman serta membuang sampah sembarangan akan mendapat sanksi. pelanggar disiplin lingkungan akan dikenakan denda sebesar Rp. 50.000,00. Pada konteks yang sama, observasi 19 Juli diperoleh data bahwa, "guru memberi tugas kepada peserta didik baru untuk membawa tanaman dalam pot. Guru menetapkan peraturan bahwa "tanaman tersebut harus dirawat dengan baik dan akan mendapat sanksi apabila tanaman tersebut mati." Temuan tersebut menunjukan terjadi penguatan disiplin lingkungan untuk mendukung kegiatan lingkungan berbasis partisipatif.

Pada tahap selanjutnya peneliti melakukan analisis terhadap peserta didik. Analisis tersebut manyangkut analisis pada kompetensi pengetahuan, sikap, dan keterampilan yang telah dimiliki peserta didik. Pertama, Pengetahuan peserta didik mengenai lingkungan dan berbagai upaya dalam menjaga kelestarian lingkungan, diperoleh melalui kegiatan lingkungan berbasis partisipatif. Beberapa indiator dari kegiatan berbasis partisitaif memberikan pengetauan kepada peserta didik tentang perlindungan lingkungan dan pencegahan kerusakan serta pencemaran lingkungan. Indikator tersebut adalah (1) sivitas sekolah terlibat dalam pemeliharaan gedung dan lingkungan sekolah; (2) sivitas sekolah memanfaatkan lahan dan fasilitas sdalam pemeliharaan gedung dan lingkungan sekolah; (2) sivitas sekolah memanfaatkan lahan dan fasilitas sekolah sesuai kaidah perlindungan dan pengelolaan lingkungan hidup; (3) adanya kreativitas dan inovasi sivitas sekolah dalam upaya perlindungan dan pengelolaan lingkungan hidup. Berikut paparan data mengenai ketiga Indikator.

Kelas bebas sampah menunjukan realisasi piket kebersihan kelas. Hal ini menunjukan bahwa peserta didik telah memiliki pengetahuan tentang perlindungan dan pengelolaan lingkungan hidup. Piket kebersihan sebagai wujud relisasi pengetahuan, namun kegiatan tersebut didorong oleh kegiatan lingkungan berbasis partisipatif, bukan melalui proses pembelajaran. Selanjutnya dipaparkan tentang pemanfaatan lahan dan fasilitas sekolah untuk kepentingan perlindungan dan pengelolaan lingkungan.

Taman kelas merupakan salah satu bentuk realisasi dari pengetahuan tentang pemeliharaan dan pengelolaan lingkungan hidup. Berikut contoh dari kegiatan kreativitas dan inovasi sivitas sekolah dalam upaya perlindungan dan pengelolaan lingkungan hidup.

Media pembelajaran miniatur gunung berapi di atas merupakan salah satu bentuk realisasi pengetahuan tentang pemeliharaan dan pengelolaan lingkungan dengan melakukan daur ulang sampah kertas menjadi benda yang lebih berharga.

Kedua, Sikap Peduli Lingkungan identik dengan pernyataan memihak terhadap perlindungan dan pengelolaan lingkungan dengan baik. Berbagai kegiatan yang dilakukan oleh peserta didik diatas menunjukan bentuk nyata dari sikap peduli terhadap lingkungan. Ketiga, Keterampilan peserta tentang perlindungan lingkungan dapat diamati pada berbagai kegiatan peserta didik. Merujuk Permendikbud (2014) keterampilan dikatakan 
sebagai penerapan pengetahuan. Berarti, beberapa kegiatan yang telah dipaparkan diatas merupakan bentuk keterampilan peserta didik pada ranah konkret tentang perlindungan dan pengelolaan lingkungan. ${ }^{11}$

Peserta didik telah memiliki pengetahuan, sikap dan keterampilan tentang pengelolaan dan perlindungan terhadap lingkungan. Kompetensi tersebut dikembangkan oleh SMP Adiwiyata kota Malang sebagai realisasi program Adiwiyata. Kompetensi yang telah dimiliki peserta didik tentang perlindungan dan pengelolaan lingkungan dibentuk oleh habitus "Kegiatan Lingkungan Berbasis Partisipatif."

Keadaan ini menandakan bahwa sikap peduli dan berbudaya lingkungan dibentuk oleh habitus peduli lingkungan di sekolah. Menurut Bourdieau, habitus menghasilkan dan dihasilkan kehidupan sosial. Disatu pihak habitus diciptakan melalui praktik/tindakan, di pihak lain habitus adalah hasil tindakan yang diciptakan kehidupan sosial (Ritzer dan Goodman, 2011). ${ }^{12}$ Habitus menyediakan prinsip-prinsip yang akan memberikan aktor sebuah pilihan dan memilih strategi yang akan digunakan dalam kehidupan sosial. Dalam kehidupan sosial terdapat sejumlah lingkungan semi-otonom seperti kesenian, keagamaan, dan ekonomi yang semuanya dengan logika membangkitkan keyakinan di kalangan aktor mengenai sesuatu yang dipertaruhkan dalam lingkungan (Ritzer dan Goodman, 2011). ${ }^{13}$ Berarti habitus peduli lingkungan melalui berbagai peraturan atau disiplin lingkungan dan kewajiban merawat sesuatu menjadi satu-satunya pilihan dan strategi dalam melakukan berbagai aktivitas dan interaksi di lingkungan sekolah.

Pengembangan pengetahuan dan pelestarian lingkungan ditekankan melalui kegiatan lingkungan berbasis partisipatif dengan disiplin lingkungan sebagai kontrol. Mempertimbangkan pernyataan Sulisantri dan Rustaman (2015) dalam laporannya bahwa, "Keberhasilan program Adiwiyata baru sampai pada pembiasaan siswa untuk bertindak tertib seperti tertib membuang sampah, tidak merusak tanaman, tidak menyakiti atau membunuh hewan, meminimalisir penggunaan kendaraan bermotor serta melaksanakan reuse, reduse dan recycle."14 Sulisantri dan Rustaman (2015) menambahkan bahwa belum terindikasi perilaku yang didasari oleh pengetahuan dan kesadaran yang mendalam. ${ }^{15}$ Sehingga dalam laporannya diasumsikan bahwa siswa hanya melaksanakan perilaku tertib di lingkungan sekolah namun belum tentu di luar sekolah. Pernyataan tersebut tidak bisa digeneralisasikan, namun patut menjadi perhatian para sivitas akademika untuk mewujudkan tujuan pendidikan nasional dan pendidikan lingkungan hidup.

${ }^{11}$ Permendikbud 58 Tahun 2014 tentang Kurikulum 2013 SMP.Pedoman Mata Pelajaran IPS

${ }^{12}$ Ritzer, G. and Goodman D.J. (2010) Teori Sosiologi Modern. Jakarta: Kencana Prenada Media Group. (halaman 523)

${ }^{13} \mathrm{Ibid}$.

${ }^{14}$ Susilastri, Dwi Susi dan Rustaman, Y. Nuryani. 2015. Student's Environmental Literacy Profile in School-Based Nature and in School that Implement the Adiwiyata Pro-gram. Makalah. Seminar Nasional Konser-vasi dan Pemanfaatan Sumber Daya Alam 2015. (halaman 268)

${ }^{15}$ Ibid. (halaman 268) 


\section{KESIMPULAN}

Upaya pihak SMP Adiwiyata Kota Malang dalam membentuk kesadaran peserta didik terkait kondisi lingkungan dan komitmen peduli lingkungan menekankan pada komponen implementasi yaitu kegiatan lingkungan berbasis partisipatif. Komponen implementasi kurikulum berbasis lingkungan dengan indikator tenaga pendidik mengembangkan isu lokal dan isu global sebagai materi pembelajaran yang terkait dengan perlindungan dan pengelolaan lingkungan hidup berada pada posisi absen. Pengembangan pengetahuan dan pelestarian lingkungan ditekankan melalui kegiatan lingkungan berbasis partisipatif dengan disiplin lingkungan sebagai kontrol. Keadaan ini menandakan bahwa sikap peduli dan berbudaya lingkungan dibentuk oleh habitus peduli lingkungan di sekolah. Habitus menyediakan prinsip-prinsip yang akan memberikan aktor sebuah pilihan dan memilih strategi yang akan digunakan dalam kehidupan sosial dan membangkitkan keyakinan di kalangan aktor mengenai sesuatu yang dipertaruhkan. Habitus peduli lingkungan yang terepresentasi pada berbagai peraturan atau disiplin lingkungan dan kewajiban merawat tanaman menjadi satu-satunya pilihan dan strategi dalam melakukan berbagai aktivitas dan interaksi di lingkungan sekolah Adiwiyata.

\section{DAFTAR PUSTAKA}

Cresswell, John W. (2012). Research Design Pendekatan Kualitatif, Kuantitatif, dan Mixed. Yogyakarta :PustakaPelajar.

Creswell, John W. 2009. Research Design Qualitatif, Quantitatif, and Mixed Methods Approaches. Third Edition. United Kingdom: Sage Publiication Ltd.

Menteri Lingkungan Hidup. 2011. Buku Panduan Adiwiyata 2011.

Peraturan Menteri Lingkungan Hidup Republik Indonesia Nomor 05 Tahun 2013 tentang Pedoman Pelaksanaan Program Adiwiyata.

Kumala, N (2014) Pengembangan Ecoliteracy melalui Tugas Pembuatan Puzzle Berbahan Dasar Barang Bekas dalam Pembelajaran IPS. (Skripsi). Jurusan Ilmu Pengetahuan Sosial. Universitas Pendidikan Indonesia.

Muhaimin. 2014. Pengembangan Model Pro-blem Based Learning dalam Ecopedagogy untuk Peningkatan Kompetensi ekologis mata pelajaran IPS. Disertasi Universitas Pendidikan Indonesia. respitory.upi.edu (Online) (diakses 26-02-2016).

Pramana, KAB (2014) Pengaruh penerapan pembelajaran PQ4R kontekstual terhadap hasil belajar IPS dan sikap peduli Lingkungan siswa kelas V SD Gugus 1 Gianyar. E 
journal Program Pascasarjana Universitas Pendidikan Ganesha Program Studi Pendidikan Dasar (Volume 4 Tahun 2014).

Ritzer, G. and Goodman D.J. 2010. Teori Sosiologi Modern. Jakarta: Kencana Prenada Media Group.Susilastri, Dwi Susi dan Rustaman, Y. Nuryani. 2015. Student's Environmental Literacy Profile in School-Based Nature and in School that Implement the Adiwiyata Pro-gram. Makalah. Seminar Nasional Konser-vasi dan Pemanfaatan Sumber Daya Alam 2015.

Terungwa, Upa Callistus dan Torkwase, Iyortyer Clara (2013) Current Issues in Flood Disaster: Challenges and Implications for Science and Technology to Enhance Environmental Education. Academic Journal of Interdiciplinary Studies. Vol 2 No. 6 Agustus 2013. 